$\begin{array}{lll}\text { KULTURA } & \begin{array}{l}\text { POLSKA A KADEMIA NAUK } \\ \text { KOMITET SOCJOLOGII }\end{array} & \text { ISSN 0023-5172 } \\ \text { i } & \text { INSTYTUT ST UDIÓW POLITYCZNYCH } & \\ \text { SPOLECZENSTWO } & 2010, \mathrm{nr} 1 \quad \text { KULTURA CODZIENNOŚCI - CODZIENNOŚĆ SPOŁECZEŃSTWA }\end{array}$

RYSZARD NECEL

Uniwersytet im. Adama Mickiewicza w Poznaniu

\title{
PALACZ PAPIEROSÓW JAKO OBCY WYBRANE STRATEGIE KONSTRUOWANIA INNEGO
}

Podejmę tu próbę wskazania praktyk służących konstruowaniu Obcego w otaczającej nas codzienności. Odejdziemy od utartej już ścieżki poszukiwań inności produkowanej na potrzeby rynku kultury popularnej i jej odbiorców. Nie interesuje nas świat freaków zamieszkany przez kosmitów, potwory czy bajkowe postacie, tak charakterystyczne dla tego, co Marek Krajewski (2003, s. 105) określił mianem kultury aliencji, czyli swoistej mody na obcość, która wabi konsumentów nieokreślonością i ambiwalencją. Główny celem, który sobie stawiam, jest opisanie dyskursywnych praktyk służących konstruowaniu obcości, której ofiarą padają miliardy ludzi na Ziemi, a w Polsce blisko dziewięć milionów rodaków. Mam na myśli palaczy papierosów, którzy oddając się codziennie „niewinnemu” nałogowi, coraz częściej traktowani są jako Inni/Obcy, którzy - co więcej - nie mogą liczyć na tolerancję ze strony większości w imię chociażby politycznej poprawności.

Przedstawiam dalej trzy sposoby konstruowania Obcego, które mają zastosowanie $\mathrm{w}$ odniesieniu do palaczy papierosów - wyróżniam praktyki dyskursywne opierające się na strategii ciała, strategiach zapachowych oraz przestrzennych. Zamierzam opisać, na czym polegają te praktyki, aby później wykazać ich siłę uprawomocnienia ujawniającą się zarówno w reklamie, kampaniach antynikotynowych, jak i w dyskursie potocznym. Zanim jednak przejdę do głównego punktu rozważań, warto poświęcić kilka słów na wyjaśnienie, co współcześnie możemy rozumieć przez kategorię obcości. Inność pojawiająca się we współczesnych obrazach przedstawiających palaczy — i praktyki wobec nich podejmowane - zostanie opisana $z$ wykorzystaniem przede wszystkim rozumienia obcości/inności zaproponowanego przez Zygmunta Baumana.

Adres do korespondencji: ryszardnecel@op.pl 


\section{OBCY NOWOCZESNY I PONOWOCZESNY}

Współczesna inność zatraciła swoją specyfikę, jest trudna do odczytania ze względu na ciągle zmieniającą się postać. To, co dzisiaj wydaje nam się obce, jutro może być swojskie bądź na odwrót. Granica My-Oni nie jest już linią demarkacyjną, której się nie przekracza, wręcz przeciwnie - jej kształt podlega procesowi ciągłej negocjacji. Obcy przez swą niedookreśloność wzbudzają $\mathrm{w}$ nas poczucie niepewności i ambiwalencję. Zdaniem Zygmunta Baumana, taki stan rzeczy charakterystyczny jest dla ponowoczesności, w której tożsamość nie jest narzucana (odgórnie dystrybuowana), ale jest projektem, który ma być przez nas konstruowany i przez nas zrealizowany. Dlaczego mówiąc o Obcym/wykluczonym/outsiderze odwołujemy się do kategorii ponowoczesnej, projektowanej, płynnej tożsamości? Otóż, zdaniem autora książki Ponowoczesność jako źródto cierpień kategoria Innego, ze swoją ambiwalencją i niedookreśleniem jako cechami dystynktywnymi, wyraża kondycję człowieka ponowoczesnego, stan jego płynnej tożsamości. „W nowych warunkach - pisze Bauman (2002, s. 50-51) — obcy nie są przejrzyście, autorytatywnie, wyselekcjonowani, zdefiniowani i wyodrębnieni - jak byli w czasach zatwierdzanych przez organa państwowe, spójnych i na długą metę opracowanych projektów ładu. Są dziś obcy tak samo nietrwali i zmienni jak własna tożsamość; podobnie jak w jej przypadku, brak im trwałego punktu zaczepienia".

Zdaniem Baumana, nowoczesność rządziła się zupełnie inną logiką, dominowało państwo, które samo określało ład i porządek, w konsekwencji też samo rysowało granicę między obcością/innością, a tym, co normalne, czyli odgórnie legitymizowane. Nietrudno było znaleźć Innego, gdyż z a s a y g ry obowiązujące w rzeczywistości społecznej były jasne i klarowne, a wszelka inność była elementem wyraźnie obcym w zaprojektowanym ładzie. Obcy ery nowoczesnej, jak pisze Bauman (2002, s. 37), „przeszkadzają temu, co państwo chce budować, i psują to, co już zbudowało. Są mętną plamą na obrazie, jaki państwo pragnęło uczynić kryształowo przejrzystym i czytelnym". W tak zaprojektowanym reżimie Inny zawsze będzie stanowić zagrożenie, dlatego też państwo podejmuje strategie mające ograniczyć lub eliminować jego negatywny wpływ. Praktyki przeciwdziałania inności możemy podzielić na antropofagiczne lub antropoemiczne (Bauman 2002, s. 38). Pierwsza polega na kulturowym kanibalizmie, czyli niwelowaniu wszelkich różnic, odmienności w imię autorytetu i ustalonych odgórnie, obowiązujących wszystkich reguł. Praktyka antropoemiczna zaś to nic innego, jak odgradzanie się od Obcych, wykluczanie ich ze „zdrowej tkanki społecznej” przez tworzenie przestrzeni zasiedlanych tylko przez Innych, swoistych gett, a niekiedy ich jawna eksterminacja. Inny nie jest tu, jak w przypadku późnej nowoczesności, towarem zawsze deficytowym, swoistym panaceum, tworzywem dla wciąż konstruowanej tożsamości.

Mamy zatem do czynienia $z$ dwiema perspektywami postrzegania Obcego, $z$ jednej strony może on być negatywną odpowiedzią na ładotwórcze 
zapędy państwa, swoistym odpadem wytworzonym w procesie uprawomocniania norm - to optyka bliska nowoczesności. Ponowoczesność proponuje patrzeć na Obcego jako na immanentny element otaczającego nas świata, jako na źródło wciąż nowych i zmiennych doświadczeń, jako na środek konstruujący naszą tożsamość.

\section{CO ZROBIĆ Z PALACZEM?}

$\mathrm{W}$ duchu ponowoczesnym powinniśmy przyjąć osobę palącą z „całym dobrodziejstwem inwentarza”, ponieważ „myśl ponowoczesną cechuje powszechne niemal przekonanie, że zróżnicowania uniknąć się nie da - i, że, co więcej, jest ono czymś dobrym, cennym, wartym ochrony i pielęgnacji" (Bauman 2002, s. 61). Nikt nie każe nam sięgać po papierosy, w końcu mamy świadomość ich negatywnego wpływu na zdrowie, Baumanowska wizja ponowoczesności wymaga jedynie minimalnej akceptacji, tolerancji wobec czyjejś inności, polegającej w tym przypadku na znajdowaniu źródeł różnorakich przyjemności w nikotynie. Odpowiedzmy sobie na pytanie, w czym ów pozytywny stosunek do czyjejś inności ma się przejawiać? Chodzi o to, by obcość nie była negatywnie piętnowana, element wyróżniający spośród innych nie stawał się powodem wykluczania ze społeczeństwa czy negatywnych reakcji innych. W przypadku palenia i palaczy mamy do czynienia z zupełnie inną sytuacją: „Palacze i palenie są powoli spychane do głębokiego kulturowego i społecznego undergroundu, nie ma dla nich tu i teraz miejsca" (Krajewski 2006, s. 105). Praktyki wykluczania palaczy odpowiadają opisanej już wyżej strategii antropoemicznej. Polega ona, jak pisze Bauman (2002, s. 38), na „wymiotowaniu obcych", czyli inaczej na usuwaniu ich poza nawias głównego nurtu życia społecznego, traktowaniu jako produkt uboczny działań ładotwórczych państwa. Przyjrzymy się teraz dokładnie sposobom konstruowania palacza jako Obcego opartych na strategiach ciała, przestrzeni oraz zapachu.

\section{STRATEGIA CIAŁA}

Nie ulega wątpliwości, że przedstawienia ciała istniały w kulturze od zawsze. Figurki przedstawiające kobiece ciało tworzono jeszcze przed narodzeniem rolnictwa (zob. Buczkowski 2005). Dlaczego przedstawienia ciała są tak ważne? Dlatego, że ciało jest nośnikiem znaczeń, przybiera formę metaforycznego tekstu, który można różnie odczytać, co jest sposobem tłumaczenia rzeczywistości, jej odzwierciedlania. Ciało, wykorzeniane z biologicznego kontekstu, w końcu naturę można udoskonalać, kontrolować, czego przykładem są chociażby operacje plastyczne, staje się „obrazem, tekstem, jest czymś bezpośrednio nam niedostępnym" (Jakubowska 2009, s. 40). Zbyszko Melosik analizuje ponowoczesne ciało $\mathrm{w}$ kontekście swoistej gry o władzę nadawania znaczeń. Dochodzi do wniosku, że istnieje wiele konkurencyjnych, często 
wykluczających się dyskursów, które walczą między sobą o „uzyskanie statusu ciała uniwersalnego [...] w każdym społeczeństwie istnieje walka różnych form wiedzy odnośnie do tego, która z nich jest prawdziwą wiedzą o ciałach" (Melosik 1996, s. 62).

W naszej kulturze dominują medialnie zapośredniczone obrazy ciał szczupłych, wysokich, wysportowanych, o urodzie, chciałoby się rzec, bez skazy, tę reprezentację można uznać za hegemonistyczną czy publicznie uprawomocnioną. Podejmowane są próby negocjowania tego wzorca, jednak jest on tak powszechny, głównie w kulturze popularnej, że ci, którzy od niego odbiegają, mogą mieć poczucie wstydu wynikające $z$ niedostosowania się do norm społecznych. Palenie papierosów, a zwłaszcza społeczny obraz palacza, przez długi czas nie stał w opozycji do ideału piękna, wręcz przeciwnie, palenie było elementem podtrzymującym, a może nawet współdefiniującym to, co składało się na atrakcyjność kulturowego ciała. Przykłady można mnożyć, wymieńmy chociaż kilka ikon popkultury: Marlboro Man, czyli postać przystojnego kowboja z papierosem jako atrybutem męskości, wolności, niezależności, Audrey Hepburn zaciągająca się tytoniowym dymem z eleganckiej cygarniczki, co nadaje wyjątkowego seksapilu jej postaci uwiecznionej na znanym zdjęciu. Przeglądając fotosy dawnych gwiazd można dojść do wniosku, że Hepburn nie jest odosobnionym przykładem. Papieros miał podkreślać atrakcyjność, stawał się wyrazem cielesnego piękna. Dzisiejszy stosunek do papierosów jako przedmiotów wyklętych oddaje historia wspomnianego zdjęcia. Osiem lat temu miało ono pojawić się na pocztowych znaczkach, niestety już po ich wydrukowaniu syn Hepburn nie zgodził się na opublikowanie w ten sposób wizerunku matki z papierosem ${ }^{1}$. Kolejnym przykładem tego, iż palenie/papieros staje się elementem współkonstruującym atrakcyjność ciała, jest ikona amerykańskiego kina James Dean, często fotografowany z papierosem.

Sztuka filmowa początku XX wieku traktowała papieros jako nieodzowny element gry aktorskiej pozwalający lepiej wyrazić stan emocjonalny granej postaci czy jej charakter: „....W latach trzydziestych papieros stał się ważnym rekwizytem w kinie — pisze Allan M. Brandt (2009, s. 342) — używanym przez postaci po to, by je wyposażyć w bogactwo różnorodnych znaczeń. Nawet pobieżny przegląd wielkich filmów lat trzydziestych i czterdziestych potwierdzi, że papieros odgrywał centralną rolę w przekazywaniu społecznych niuansów życia codziennego".

Spójrzmy, w jaki sposób współczesny film traktuje palacza i jego reprezentacje. Dziś amerykański przemysł rozrywkowy coraz częściej usuwa czynność palenia nikotyny ze swoich produkcji. W filmie, głównie w tym amerykańskim, jeżeli ktoś pali, jest zazwyczaj złym charakterem (tajemniczym mordercą czy

1 Jeden $z$ ocalałych znaczków był wystawiony na aukcji w Berlinie, a jego cena wywoławcza wynosiła 30 tysięcy euro (http://www.chillizet.pl/Kultura/Swiat/Hepburn-z-papierosem [20.01.2010]). 
pospolitym rzezimieszkiem). Jedna z ostatnich głośnych produkcji, w których papieros jest atrybutem ciała pięknego, seksownego, budzącego zainteresowanie, to legendarny już film Pulp Fiction. Mia, postać, w którą wcieliła się Uma Thurman, jest żoną gangstera Marsellusa Wallace'a. Wykorzystując swoją atrakcyjność fizyczną, seksapil podkreślony paleniem papierosa, uwodzi pracującego u jej męża Vincenta Vegę.

Powyższe przykłady należą już do historii, dzisiaj media nie upowszechniają obrazu palenia jako reprezentacji tego, co zmysłowe czy seksualne. Wystarczy spojrzeć na zdjęcia współczesnych idoli popkultury. Celebryta, filmowa gwiazda nie pozuje z papierosem, jak Hepburn czy Dean, używka ta nie podbudowuje już ideału piękna. Na papierosie można być jedynie „przyłapanym” jako na czynie z gruntu złym, obnażającym prawdziwą naturę gwiazdy, na czym żerują tabloidy lub plotkarskie serwisy. Przykładem może być chociażby strona internetowa plejada.pl, gdzie pokazano zdjęcia gwiazd muzyki, filmu z papierosem, zrobione $z$ ukrycia, a okraszone takim komentarzem: „Palenie szkodzi — to hasło znają wszyscy. Ponieważ od lat już puszczanie dymka jest passé gwiazdy pilnują, by nie dać się przyłapać z papierosem $w$ ręku, albo, co gorsza, w ustach. Niektórym jednak się to nie udało. Zobacz galerię gwiazd przyłapanych z papierosem" 2 . Wydaje się, iż jedynym tekstem kultury popularnej, w którym papieros nie został ocenzurowany, są filmy lub seriale odnoszące się do przeszłości. Wtedy reprezentacje palących mają oddawać „ducha epoki”, wprowadzić widza w klimat tamtych lat. Przykładem może być tutaj serial Mad Man z akcją rozgrywającą się w latach sześćdziesiątych ubiegłego stulecia.

Powyższe przykłady pokazują, jak zmieniły się reprezentacje papierosów w kulturze popularnej: od używki potęgującej, podkreślającej fizyczną atrakcyjność aż po coś, co jest zupełnie wykluczone $z$ medialnych reprezentacji. Strategia ciała polega więc na dewaluowaniu papierosów jako rekwizytu, posługując się terminologią Goffmana, który do cielesnych kanonów piękna nie pasuje, a wręcz im zaprzecza.

Praktyki wykorzystania ciała do konstruowania obrazu palaczy jako Obcych/Innych/wykluczonych mają jeszcze jedną postać, stosowaną najczęściej $\mathrm{w}$ różnorakich kampaniach antynikotynowych i polegającą na eksponowaniu ciała palacza jako ciała potwora czy trudnego do zidentyfikowania monstrum. Buduje się obraz nadużywającego nikotynę jako tego, kto zagrożony jest cielesnym wyobcowaniem. Media wciąż promujące, eksponujące ciała piękne, zdrowe, wysportowane, jednocześnie piętnują wszystko to, co owego ideału nie reprezentuje. Wykluczony jest więc ten, kto ma ciało grube, stare, niepełnosprawne itd., także ten, kto jest palaczem. Jest to przede wszystkim dyskurs zdrowia i urody. Wybrane „przewinienia” palacza wobec swej cielesności to:

\footnotetext{
2 http://www.plejada.pl/7906,9,17,gwiazdy-przylapane-z-papierosem,fotogaleria.html [20.01. 2010].
} 
utrata włosów, wiotczenie i marszczenie się skóry, próchnica zębów, przebarwienia palców itd.

Niepodważalnym dowodem istnienia owej strategii ciała są zdjęcia, obrazy wykorzystywane $\mathrm{w}$ antynikotynowych kampaniach przedstawiające ciało palacza jako ciało nieludzkie, obce, budzące strach, obrzydzenie, przerażenie, niczym postać potwora tak często pojawiająca się $\mathrm{w}$ tekstach popkulturowych. Przykładem może być chociażby propozycja Międzynarodowej Organizacji Zdrowia, aby na paczkach papierosów pojawiały się obrazkowe ostrzeżenia o szkodliwości papierosów. Mają tam być przedstawiane organy ludzkie skażone rakiem czy innymi schorzeniami, co powinno nikotynę obrzydzić, odstraszyć od używki. Tego typu zabiegi wizualne potęgują jednak proces dehumanizacji czynności palenia. Palacz nie jawi się nam już jako człowiek, jest postrzegany przez zdeformowane płuca, zniszczone serce czy nienaturalnie zniszczoną przez próchnicę szczękę, dominują ropne wybroczyny, czarne skazy na sercu i płucach. Do podobnej konkluzji dochodzi Richard Klein, autor książki Papierosy sa boskie, analizując współczesne fotografie osób palących i porównując je z wizualnymi przedstawieniami dominującymi w ubiegłym stuleciu: „Czasami zaśmiewam się oglądając pewne zdjęcia. Niektóre są piękne, inne wzruszające, ale wszystkie pobudzają do śmiechu. Pytam się, czy jest coś z natury komicznego lub dowcipnego $\mathrm{w}$ obrazie ludzi palących papierosy? Można by rzec, że nie dzisiaj: w obecnym klimacie intelektualnym, przy dźwiękach bicia na alarm za każdą fotografią zdaje się czaić zdjęcie rentgenowskie, na którym widać umęczone płuca palacza" (Klein 1998, s. 146).

Uzależniony od nikotyny odarty jest więc z człowieczeństwa, a samemu paleniu odbiera się wcześniejsze kulturowo nadane znaczenia, jednak dla dobra sprawy akceptujemy owe reprezentacje. Jeszcze kilkanaście lat temu reklamy papierosów miały promować takie społecznie pożądane wartości jak przyjaźń, niezależność, indywidualizm, poczucie kontroli czy bezpieczeństwa. Dziś reklama papierosów jest zakazana, a rozwijana $\mathrm{w}$ formie różnorakich kampanii antyreklama nikotyny zwykle odziera człowieka $z$ wszelkich form podmiotowości.

Obok reprezentacji organów ludzkich strategie ciała stosowane w kampaniach antynikotynowych proponują obraz palacza jako niby-człowieka, swoistego freaka, którego wygląd bardzo odbiega od tego, co uznajemy za normalne. Spotkać więc możemy człowieka $z$ wielką naroślą na gardle czy ze zdeformowaną przez raka twarzą. Ich ciała nie przypominają już ciał ludzkich, są ciałami potwora, będącego synonimem tego, co niemoralne, złe, o niespotykanym kształcie i brzydocie (Brzozowska-Brykczyńska 2007, s. 2).

Strategia ciała $\mathrm{w}$ przypadku konstruowania obrazu palacza operuje więc cielesnymi stygmatami. „Na poziomie ciała — pisze Honorata Jakubowska (2009, s. 184) - stygmatem może być wszystko to, co nie pasuje do obowiązujących w danej kulturze wzorców piękna, na przykład otyłość czy krzywe nogi, niepełnosprawność, a także coraz częściej naturalne (niepoprawione) 
ciało, na przykład brak makijażu czy depilacji w przypadku kobiet". Swoistym piętnem palącego ma być wygląd zewnętrzny, chociażby kondycja skóry, paznokci, zębów. Przez stosowanie strategii ciała antynikotynowe kampanie chcą nam przekazać wiadomość: jeśli decydujesz się na palenie, to skazujesz się tym samym na piętno wykluczenia, twój wygląd będzie odstawać od przyjętych kanonów piękna, możesz przeistoczyć się w Obcego, anormalnego potwora, dotychczas spotykanego jedynie w wytworach fikcji popkultury.

Przykładem opisywanych strategii ciała może być kampania antynikotynowa „HELP dla życia bez tytoniu”, finansowana przez Komisję Europejską. Ostatnim z jej etapów są realizowane w 2010 roku krótkie (półtoraminutowe) filmy rysunkowe mające skłonić Europejczyków do rzucenia palenia ${ }^{3}$. Na razie zaprezentowano jedynie cztery odcinki. Bohaterowie to Chuck, Skinny, Loona i Tapas, toczą oni otwartą wojnę z palaczami tytoniu, pomagają rzucić zgubny nałóg czy ratują innych od biernego palenia. Mają przykre doświadczenia $z$ paleniem i postanawiają wysadzić $\mathrm{w}$ powietrze fabrykę tytoniu. Plan się powiódl, jednak w zetknięciu z zieloną cieczą stosowaną do produkcji tytoniu ich ciała ulegają transformacji, stają się superbohaterami, ale już nie ludźmi. $\mathrm{Z}$ punktu widzenia naszych analiz ważne jest konstruowanie w tych anonimowych produkcjach obrazu palacza, który cielesnym wizerunkiem wyróżnia się wśród współpasażerów: jego skóra jest zielona, ma wielkie oczy koloru czarnego, a z nozdrzy wypływa mu zielona ciecz. W miarę pojawiania się na stronie internetowej kampanii kolejnych odcinków można będzie stwierdzić, czy przedstawianie palacza jako Obcego/Innego było incydentalne, czy też stanowiło zabieg celowy.

\section{STARTEGIA ZAPACHU}

Cielesne reprezentacje palacza, które można zaliczyć do strategii wykluczania, odwołują się również do zapachu ciała palacza. „To, co kiedyś uważano za zachowanie będące kwintesencją wyrafinowania - pisze Patrick W. Corrigan w artykule Marlboro Man i piętno spoteczne palacza (2009, s. 354) stało się czynnością ordynarną: Palenie śmierdzi i zabija! [...] Palacze są śmierdzącymi smutnymi ludźmi, którzy stanowią fizyczne i moralne zagrożenie dla społeczeństwa. Co za tym idzie, palacze stają się napiętnowaną grupą". Odwołując się w opisie palacza do jego nieprzyjemnego zapachu z ust czy woni ubrań przesiąkniętych tytoniowym dymem, podkreśla się inwazyjność przykrych konsekwencji palenia. Cielesne zmiany zachodzące, według wiedzy potocznej, na skutek nałogu, jak chociażby przebarwienia skóry, wypadanie włosów itp., są neutralne dla otoczenia palącego i pod tym wzglę-

\footnotetext{
3 http://pl.helpers-eu.com/ [21.01.2010].
} 
dem może on zarządzać swoim ciałem w wybrany przez siebie sposób. Jednak nieprzyjemny zapach ciała narusza bezwonny obszar innych aktorów życia społecznego, stając się tym samym argumentem na rzecz wykluczania palaczy.

Dym papierosowy oraz jego społeczna percepcja, która każe definiować go głównie jako zapach szkodliwy dla zdrowia (z tym faktem trudno polemizować), nieprzyjemny, drażniący, inwazyjny, to także element służący konstruowaniu palaczy jako Obcych/Innych i dla przeciwników nikotyny silny argument za wykluczeniem jej z przestrzeni życia społecznego. Aby dobrze wytłumaczyć, na czym polega strategia oparta na zapachu, należy najpierw nadać jej odpowiedni kontekst kulturowy, mianowicie w rzeczywistości, w której żyjemy, dominuje kultura bezwonna. Cytowany już Marek Krajewski (2003, s. 249) stwierdza, że współcześnie mamy do czynienia z kulturą aromatyzacji, w której normą jest zapachowa neutralność, powszechna zwłaszcza w krajach zachodnich. Dym papierosowy łamie wszelkie nakazy bezwonności, wymyka się społecznej kontroli nad zapachem.

Współcześnie zmysł powonienia poddany jest $z$ jednej strony procesowi naturalizacji, z drugiej zaś kulturalizacji (Krajewski 2003, s. 287). Proces naturalizacji czyni ze zmysłu powonienia jeden z podstawowych środków doświadczania rzeczywistości. Dym ze względu na swój wyrazisty, charakterystyczny, dla niepalącego nieprzyjemny zapach staje się elementem doświadczania otaczających nas przestrzeni. W żadnej mierze nie jest już ona neutralna, ponieważ została zainfekow an a przez dym. Jednocześnie proces kulturalizacji zapachów wyposaża nas $\mathrm{w}$ etykietę dotyczącą posługiwania się zmysłem powonienia, co pozwala na tworzenie hierarchii zapachów (Krajewski 2003, s. 287), jedne są traktowane jako przyjemne, chcemy przebywać $\mathrm{w}$ ich otoczeniu, konsumować je; inne zaś poddawane są wykluczaniu. Woń papierosów zinternalizowane już normy klasyfikacji każą nam potraktować jako nie tylko wyjątkowo szkodliwą dla zdrowia, ale także nieprzyjemną, odstręczającą.

Woń dymu wydzielana przez papieros staje się kolejnym elementem wykluczającym palacza, czyniąc $z$ niego jednostkę obcą, nie potrafiąca podporządkować się społecznie uznanym normom. Celem strategii zapachowej jest odzyskanie przestrzeni kolonizowanych przez dym. Najpowszechniejszą praktyką jest wprowadzanie zakazów palenia, coraz częściej w przestrzeni publicznej możemy spotkać napis „Strefa wolna od dymu papierosowego”. W sukurs strategii zapachowej przychodzą wynalazki techniczne: klimatyzacja w pubach czy restauracjach, elektroniczne odświeżacze, pochłaniacze dymu. Coraz popularniejsze stają się również elektroniczne papierosy, które nie emitują papierosowego dymu, dzięki czemu palacz pozbywa się piętna wykluczenia, nie jest już Obcym, który narusza bezwonną przestrzeń. „Smak elektronicznego papierosa - pisze jeden z producentów tego wynalazku - jest stworzony przez największych specjalistów od tytoniowego aromatu. Nie pozo- 
stawia jednak przykrej woni $\mathrm{w}$ miejscu palenia i nie szkodzi innym niepalącym" ${ }^{4}$.

\section{STRATEGIA HETEROTOPICZNA}

W celu zrozumienia istoty kolejnej strategii transformowania osoby palącej w Obcego należy najpierw wyjaśnić kategorię heterotopii. Według francuskiego myśliciela Michela Foucaulta odnosi się ona do przestrzeni, w których realizowane są taktyki radzenia sobie $z$ obcością, przy czym wyróżnić można dwie podstawowe kategorie (Foucault 1986, s. 24). Pierwsza to występujące w społeczeństwach prymitywnych obszary wyłączone przeznaczone dla tych, którzy doświadczali ważnego dla społeczności momentu przejścia. Jednostki zamieszkujące owe miejsca to na przykład: młodzież w okresie dorastania, kobiety w okresie menstruacji, kobiety w ciąży czy ludzie starsi — Foucault przestrzenie te określa mianem heterotopii kryzysu. Druga kategoria przestrzeni wyłączonych to heterotopie dewiacji, które francuski myśliciel opisuje w następujący sposób: „Myślę, że dzisiaj heterotopie kryzysu zastępowane są przez to, co nazwać byśmy mogli heterotopiami dewiacji, w których umieszczane są jednostki, które wykazują dewiacyjne zachowania wobec przyjętych nakazów i norm". Autor wymienia przykładowe heterotopie dewiacji: szpitale psychiatryczne, więzienia czy domy spokojnej starości (Foucault 1986, s. 24).

$\mathrm{Na}$ czym polega strategia heterotopii $\mathrm{w}$ przypadku palaczy papierosów? Chodzi przede wszystkim o wyznaczanie pewnych miejsc, w których umieszczamy palaczy - przestrzeni wyłączonych i przeznaczonych na ich dewiacje. W Polsce kilkanaście lat temu problem ten nie istniał, gdyż palić można było prawie wszędzie. Miejsca pracy, budynki użyteczności publicznej, środki transportu nie były wolne od papierosowego dymu. Mówiąc o heterotopiach dewiacji w przypadku palaczy mam na myśli wszystkie miejsca naznaczone tabliczką „Tu wolno palić”, czyli wyraźnie wydzielone przestrzenie na dworcach kolejowych czy autobusowych, specjalne przedziały kolejowe, pokoje dla palaczy, tzw. palarnie, w których uzależniony, nie przeszkadzając nikomu, może oddać się paleniu. $Z$ heterotopiami mamy do czynienia wtedy, gdy wyznacza się przestrzeń, poza którą określone zachowanie jest zabronione, tak jak chory może być naprawdę sobą tylko w szpitalu psychiatrycznym, tak palacz tylko $\mathrm{w}$ wyznaczonym miejscu może ujawnić się ze swoim nałogiem.

Od pewnego czasu jesteśmy świadkami społecznego sporu o heterotopie dla palaczy. Jeszcze niedawno system tolerował Obcego w postaci palacza, wyznaczał mu jedynie przestrzeń wolną od kulturowej normy niepalenia. Dzisiaj zaś coraz częściej mówi się o odebraniu uzależnionym od nikotyny, współczesnym Obcym, ostatniego bastionu, w którym mogli się oddawać coraz mniej ak-

\footnotetext{
4 http://www.tvn24.pl/26086,1563310,0,1,papieros-na-baterie-_-nadzieja-palaczy,wiadomosc. html [29.01.2010].
} 
ceptowanemu nałogowi. Najlepszą eksplikacją tych zmian jest projekt ustawy sejmowej o całkowitym zakazie palenia w miejscach publicznych. Jest to systemowe rozwiązanie, które nagle ma likwidować wszelkie przestrzenie przeznaczone dla naszych Obcych. Projekt bowiem zakłada całkowity zakaz palenia w miejscach publicznych, w lokalach gastronomiczno-rozrywkowych (wyjątek to lokale z pomieszczeniem służącym wyłącznie do palenia) ${ }^{5}$.

Okazuje się, iż heterotopie jako pewien sposób radzenia sobie $z$ obcością przez jej wyizolowanie, wykorzenienie z życia społecznego oraz stworzenie enklaw, w których inność jest dozwolona, to jedynie projekt przejściowy. Dąży się bowiem do ostatecznego rozstrzygnięcia, jakim powinno być zupełne wyrugowanie palacza ze sfery publicznej. Stosując kategorie pojęciowe Baumana można powiedzieć, że najpierw mieliśmy do czynienia ze strategią antropoemiczną wobec palaczy. Polegała ona na „...zamykaniu obcych wewnątrz solidnych murów getta lub niewidzialnych, ale nie mniej szczelnych ścian murowanych z zakazów commercium, commensalium i connumbium" (Bauman 2002, s. 38). Był to jednak stan chwilowy, gdyż państwo idzie dalej, likwidując owe heterotopie, wprowadza w życie to, co określić możemy jako asymilację, czyli tępienie wszelkich różnic. Wymusza się więc przez zakazy uległość wobec państwa, które pozbywa się Obcych jako oznaki swojej słabości. Strategie heterotopii stosowane wobec palaczy i opisane ich przemiany są bodaj najlepszym dowodem wciąż ważnej roli państwa jako legislatora. „Zakazy palenia wydawane przez kolejne miasta i dotyczące również przestrzeni prywatnych (puby, restauracje) nie są więc przejawem troski o stworzenie warunków samosterowności obywateli, ale raczej ujawniają, że państwo istnieje, oraz że jego struktury są sprawne. Zakazywanie palenia dowodzi też, że pogłoski o śmierci państw narodowych są przedwczesne, bo w dalszym ciągu mają one zdolność regulowania zachowań obywateli" (Krajewski 2006, s. 105).

\section{PALENIE W PRZESTRZENI DOMOWEJ, CZYLI HETEROTOPIE NA CO DZIEŃ}

Dotychczas o heterotopiach mówiliśmy z perspektywy miejsc przeznaczonych dla Obcych, w naszym przypadku palaczy, wyznaczanych przez państwo wprowadzające określony ład normatywny w odniesieniu do przestrzeni publicznych. Jednak z przestrzennymi praktykami radzenia sobie z palaczem jako Innym mamy również do czynienia w życiu codziennym. Przykładów dostarczają badania socjologiczne przeprowadzone przez Instytut Socjologii w Poznaniu we współpracy z Akademią Sztuk Pięknych na temat różnych form zamieszkiwania (zob. Wołyński 2010). Nasi rozmówcy (warto wspomnieć, iż żaden nie zdeklarował się jako osoba paląca), na pytanie, czego nie wolno robić $\mathrm{w}$ domu, co jest zakazane, w większości zwracali uwagę na obowiązujący w ich

\footnotetext{
5 http://www.nasz-parlament.pl/ustawa?id=13 [21.01.2010].
} 
domostwach zakaz palenia. Norma ta nie przybierała jednak formy asymilacji, czyli zupełnego pozbycia się palącego z przestrzeni domowej, gdyż mieszkańcy radzili sobie $\mathrm{z}$ innością palacza $\mathrm{w}$ ten sposób, że wyznaczano pewne obszary, w których zakaz ten nie obowiązywał. Do tego typu domowych heterotopii można zaliczyć balkon.

Siedemdziesięciopięcioletnia rozmówczyni tak odpowiada na pytanie badacza: „Czego nie wolno robić u Pani w domu?”:

„Wie Pan, że nie umiem odpowiedzieć. Pijaństwa nie toleruje, alkohol jest oczywiście dla ludzi, ale to lampka wina, czy tak. Ale że miałby się ktoś tutaj upić, to bym tego nie zniosta po prostu. Też niechętnie jak ktoś pali papierosy. Chociaż wiem, że moi znajomi, którzy jeszcze pala, a jest takich niewiele, to nie korzystają z tego, żeby u mnie zapalić. Jeżeli pala, to jak mam jakaśs awarię wody, to przychodza robotnicy, ale wtedy też otwieram balkon i bardzo proszę, balkon jest duży, zadaszony" (K, 75).

Balkon jako jedyną przestrzeń domową, w której możliwe jest palenie papierosów, wskazywali również inni rozmówcy:

„No, na przyktad my nie palimy $i$ ja bym nie chciat, znaczy nie pozwolitbym komuś palić, znaczy jeśli ktoś pali, sporadycznie takie osoby sa, to wtedy maja na balkonie wystawione... Nie byto takiej sytuacji... To znaczy, ta osoba sie pytała, czy może, i wtedy wychodzili... Nie że wyjmowat ktoś papierosa $i$ zaczynat palić, tylko na ogót sami sie pytali, wiedząc, że my nie palimy, to pytali się, czy moga zapalić... To byli na balkonie, zreszta zawsze to byto lato... Chociaż nie, bo w Sylwestra też tam palili znajomi... to też na balkonie palili. Nie byto to dla nikogo problemem, a dla mnie by może byto, gdyby $k$ toś $w$ pomieszczeniu palit. Akurat mnie, jako niepalacego, nas, jako niepalacych, drażni ten dym" (M, 35).

Do miejsc, w których nie obowiązuje zakaz palenia, można zaliczyć również kuchnię:

„Wiesz, jeżeli ktoś przychodzi do nas, pali na przyktad papierosy, to wie, że siedzimy tutaj $i$ w pewnym momencie ma ochotę na fajki, to wychodzi do kuchni. Bo wie, że nie palimy $w$ pokoju, no bo nie palimy $w$ ogóle, $w$ ogóle się nie pali w pokoju, jest dziecko małe i tak dalej. Mama pali, mama pali też $w$ kuchni, w pokoju u siebie nawet też nie pali, tak że jest taki zwyczaj $i$ ten, kto tu przychodzi tutaj któryś już tam raz, n-ty, dziesiaty, piętnasty, no to wie: „A, to ja idę sobie zapalic” (M, 24).

W wywiadach przeprowadzonych $z$ mieszkańcami Poznania na temat ich percepcji pojęcia „dom” czy też praktyk dozwolonych i zakazanych w przestrzeni zamieszkania stosunkowo często pojawiała się kwestia radzenia sobie z Innym w postaci palącego papierosy. Palaczowi w sferze domowej, podobnie jak w przestrzeni publicznej, wyznacza się ściśle określone zony, w których ewentualnie może oddawać się zgubnemu nałogowi. Warto podkreślić, iż zawsze jest to przestrzeń, do której trzeba się specjalnie udać, przestrzeń wykluczona $z$ głównego nurtu praktyk towarzyskich, co wymaga od palacza wyłączenia się z absorbującej rozmowy czy czynności na czas poświęcony papierosowi. 
Palacz jest zatem jednym ze współczesnych Obcych, o czym świadczą stosowane strategie cielesne, zapachowe czy przestrzenne. Każda z nich w inny sposób podkreśla inność tego, kto jest uzależniony od nikotyny. Strategia ciała polega głównie na operowaniu obrazem. Zdjęcia pojawiające się na paczkach papierosów czy obrazy stosowane w kampaniach antynikotynowych epatują fragmentami ciał brzydkich, zniekształconych, wręcz zdewastowanych przez zgubną używkę, umacniając tym samym dehumanizującą perspektywę postrzegania palącego. Przykładem praktyk cielesnych stosowanych w konstruowaniu Obcego jest palacz-potwór, czyli wszystkie te obrazy, w których wygląd palacza przerażająco odbiega od tego, co uznane za normalne. Innym sposobem konstruowania Obcego jest strategia zapachowa. To dzięki dymowi podważającemu kulturową normę bezwonności, palacz staje się wrogiem numer jeden, Obcym wobec, którego stosuje się procesy wykluczenia.

Kolejną strategię określiliśmy mianem przestrzennej, gdyż polega na lokacyjnych praktykach radzenia sobie $z$ innością. Chcąc kontrolować dewiacyjną czynność palenia, wyznacza się wyraźne granice, poza którymi korzystać z papierosa nie wolno. Wszelkiego typu palarnie były jednak etapem przejściowym, gdyż zwycięża strategia asymilacji, w imię której coraz częściej likwiduje się enklawy palaczy.

\section{BIBLIOGRAFIA}

Bauman Zygmunt, 2002, Ponowoczesność jako źródto cierpień, Sic!, Warszawa.

Buczkowski Adam, 2005, Społeczne tworzenie ciała. Płeć kulturowa i pteć biologiczna, Universitas, Kraków.

Brandt M. Allan, 2009, Budowanie świadomości konsumenckiej w XX wieku, w: Sander L. Gilman, Zhou Xun (red.), Dym. Powszechna historia palenia, tłum. Jagoda Sochoń-Jasnorzewska, Universitas, Kraków.

Brzozowska-Brykczyńska Maja, 2007, Monstrous/Cute. Notes on the Ambivalent Nature of Cuteness, w: Niall Scott (red.), Monster and the Monstrous: Myths and Metaphors of Enduring Evil, Rodopi, Amsterdam-New York.

Corrigan W. Patrick, 2009, Marlboro Man i piętno spoteczne palacza, w: Sander L. Gilman, Zhou Xun (red.), Dym. Powszechna historia palenia, tłum. Jagoda Sochoń-Jasnorzewska, Universitas, Kraków.

Foucault Michel, 1986, Of Other Spaces, „Diacritics”, t. 16, nr 1.

Klein Richard, 1998, Papierosy sa boskie, tłum. Jacek Spólny, Czytelnik, Warszawa.

Jakubowska Honorata, 2009, Socjologia ciała, Wydawnictwo Naukowe UAM, Poznań.

Krajewski Marek, 2003, Kultury kultury popularnej, Wydawnictwo Naukowe UAM, Poznań.

Krajewski Marek, 2006, POPamiętanie, słowo/obraz terytoria, Gdańsk.

Melosik Zbyszko, 1996,Tożsamość, ciało i władza. Teksty kulturowe jako (kon)teksty pedagogiczne, Edytor, Poznań-Toruń.

Wołyński Piotr (red.), 2010, Formy zamieszkiwania. Domostwa w obrazach — poznaniaków portret zbiorowy, Akademia Sztuk Pięknych w Poznaniu, Poznań. 
THE SMOKER AS THE OTHER.

\section{SOME STRATEGIES OF CONSTRUCTION OF THE OTHER}

\section{Sum mary}

The author concentrates on some cultural strategies which have made an Other from people who smoke cigarettes. The article is based on the concept of the Other presented by Zygmunt Bauman. The author analyzes three basic strategies: strategy of cultural body, strategy of heterotopia and strategy of odour which dominate in the manner in which smokers are separated. Through body, place and smell modern culture defines smokers as an Other which differs from the socially accepted norms and is continually and increasingly excluded from mainstream society.

\section{Key words/słowa kluczowe}

The Other / Obcy, Inny; cultural body / ciało kulturowe; smoker / palacz; odour / zapach; heterotopias / heterotopie; methods of exclusion / strategie wykluczania 